\title{
Journey of Regionalism On and Along the Track of Nationalism and Federalism in Indian Democracy- A Critical Geo-Political Analysis
}

\author{
Rabin Das ${ }^{1}$, Ramu Guchhait ${ }^{2}$ \\ ${ }^{1}$ Assistant Professor of Geography, Bajkul Milani Mahavidyalaya (V.U.) \\ ${ }^{2}$ Guest Lecturer of Geography, Bajkul Milani Mahavidyalaya (V.U.)
}

\begin{abstract}
Regionalism in Indian Politics is fast spreading across various states of India. It has become a striking feature of the Indian political party system. The rise of regional political parties have played significant role in the regional, state and even national politics of our democratic country. After the first general election of 1952, the Election Commission had declared 19 political parties as regional parties. In fact, the regional political parties have become a part and parcel of Indian political system. The term Regionalism has two connotations. In the negative sense, it implies excessive attachment to one's region is preference to the country or the state. In the positive sense it is a political attribute associated with people's love for their region, culture, language, etc. with a view to maintain their independent identity. While positive regionalism is a welcome thing in so far maintaining as it encourages the people to develop a sense of brotherhood and commonness on the basis of common language, religion or historical background. The negative sense regionalism is a great threat to the unity and integrity of the country. In the Indian context generally the term regionalism has been used in the negative sense. The feeling of regionalism may arise either due to the continuous neglect of a particular area or region by the ruling authorities or it may spring up as a result of increasing political awareness of backward people that have been discriminated against. Quite often some political leaders encourage the feeling of regionalism to maintain their hold over a particular area or group of people. So, the emphasis of this paper based on geo-political analysis are to analyze the factors responsible for the growth of regionalism, determine the factors instrumental for the growth of regional parties, create awareness about the role of regional parties, to distinguish a regional party from a national party, enumerate the roles of Political Parties in Balancing Federalism and Regionalism, assess the roles of regionalism on politics and suggestive Measures for Correcting Regional Imbalances.
\end{abstract}

Keywords: Regionalism, regional party, political awareness, geo-political analysis and Regional Imbalances.

\section{Introduction}

To understand regionalism, we need to know various dimensions of the region. Region as a geographical unit, is delimited form each other. Region as a social system, reflects the relation between different human beings and groups. Regions are an organized cooperation in cultural, economic, political or military fields. Region acts as a subject with distinct identity, language, culture and tradition. Regionalism is an ideology and political movement that seeks to advance the causes of regions. As a process it plays role within the nation as well as outside the nation i.e. at international level. Both types of regionalism have different meaning and have positive as well as negative impact on society, polity, diplomacy, economy, security, culture, development, negotiations, etc. At the international level, regionalism refers to transnational cooperation to meet a common goal or to resolve a shared problem or it refers to a group of countries such as-Western Europe, or Southeast Asia, linked by geography, history or economic features. Used in this sense, regionalism refers to attempts to reinforce the links between these countries economic features. The second meaning of the term is regionalism at national level refers to a process in which sub-state actors become increasingly powerful; power devolves from central level to regional governments. These are the regions within country, distinguished in culture, language and other sociocultural factors. Now, we will discuss in detail about regionalism within nation with respect to India only.
One of the notable features of the Indian Party System is the presence of a large number of regional parties. By regional party we mean a party which generally operates within a limited geographical area and its activities are confined only to a single or handful of states. Further as compared to the broad ranging diverse interests of national parties, the regional parties represent the interest of a particular area. In simple words, regional parties differ from All India parties both in terms of their outlook as well as the interests they pursue. Their activities are focused on specific issues concerning the region and they operate within the limited area. They merely seek to capture power at the state or regional level and do not aspire to control the national government. It is noteworthy that in India, the number of regional parties is much larger than the national parties and some of the States are being ruled by the regional parties, viz., Andhra Pradesh, Tamil Nadu, Karnataka, Assam, Bihar, Uttar Pradesh, West Bengal, Jammu \& Kashmir etc.

\section{Objectives}

After studying this lesson, you will be able to

- analyze the factors responsible for the growth of regionalism;

- determine the factors instrumental for the growth of regional parties;

- create awareness about the role of regional parties;

- Distinguish a regional party from a national party;

- Role of Political Parties in Balancing Federalism and Regionalism; 


\section{International Journal of Science and Research (IJSR) \\ ISSN (Online): 2319-7064 \\ Index Copernicus Value (2013): 6.14 | Impact Factor (2014): 5.611}

- Role of Regionalism on politics; and

- Suggestive Measures for Correcting Regional Imbalances.

\section{What is Regionalism?}

The term regionalism" has two connotations. In the negative sense, it implies excessive attachment to one's region is preference to the country or the state. In the positive sense it is a political attribute associated with people's love for their region, culture, language, etc. with a view to maintain their independent identity. While positive regionalism is a welcome thing in so far maintaining as it encourages the people to develop a sense of brotherhood and commonness on the basis of common language, religion or historical background. The negative sense regionalism is a great threat to the unity and integrity of the country. In the Indian context generally the term regionalism has been used in the negative sense.

Regionalism is a feeling or an ideology among a section of people residing in a particular geographical space characterized by unique language, culture etc. and the feeling that they are the sons of the soil and every opportunity that exists in their land must be accorded to them first and not to the outsiders. It is a sort of Parochialism. In most of the cases it is raised for expedient political gains.

The feeling of regionalism may arise either due to the continuous neglect of a particular area or region by the ruling authorities or it may spring up as a result of increasing political awareness of backward people that have been discriminated against. Quite often some political leaders encourage the feeling of regionalism to maintain their hold over a particular area or group of people.

\section{Different Forms of Regionalism}

Acc. to Dr. D.C. Gupta, the following are the main forms of regionalism in India or it has got manifested in the following four forms:-

a) Demand for State Autonomy: Regionalism has often led to the demand by states for greater autonomy from the center. Increasing interference by the Centre in the affairs of the states has led to regional feelings. Demand for autonomy has also been raised by regions within some states of the Indian federation.

b) Secession from the Union: This is a dangerous form of regionalism. It emerges when states demand separation from the Centre and try to establish an independent identity of their own.

c) Demand for Full statehood: In India, Most of the Union Territories were not in favour of 14th amendment of the constitution. Therefore, as consequence, the Union territories of Himachal Pradesh, Manipur, Tripura, Meghalaya and Goa were granted the status of full statehood and the remaining union territories are demanding full statehood.

d) Inter-State Disputes: Today, many states are making demands for the merger of territory of belonging to other states and for just division of river waters. Disputes between states over the sharing of river water, primacy given by the states to the language of majority and to people of their own states in job opportunities have also given rise to feelings of regionalism. Migration of people from backward state to a developed state for employment opportunities have often resulted in a hostile attitude against the migrants for example, problems going on in Karnataka and A.P.

\section{Development of Regionalism in India}

Regionalism is not a new phenomenon in the Indian political system. In the pre-independence days it was promoted by the British imperialists and they deliberately encouraged the people of various regions to think in terms of their region rather than the nation as a whole, with a view to maintain their hold over India during the national movement. After Independence the leaders tried to foster a feeling among the people that they belonged to one single nation. The framers of the constitution sought to achieve this by introducing single citizenship for all. With the same objective a unified judiciary, all Indian services, and a strong Central government was provided. But in view of the vastness of the country and cultures regionalism soon made its appearance in India.

The first manifestation of regionalism was the demand for reorganization of states on linguistic basis, but the most effective play of regionalism was the victory of the DMK against Congress in Tamil Nadu in 1960s. Initially the central leadership felt that regionalism was a peripheral political factor confined to Tamil Nadu and hence did not pose any threat to national unity. However, that assessment was ill-founded. Soon in Punjab the Akali movement gained momentum, while in Jammu and Kashmir Sheikh Abdullah revived the National Conference. During these initial years all the Indian political parties continued to adjust with these regional forces on the plea that they would ultimately succeed in making inroads into the bases of the regional parties and absorb them in their organizations.

The Indian National Congress which enjoyed monopoly of power between 1947-1967 and followed a policy of blowing hot and cold toward the regional forces, also contributed to the growth of regionalism in India. It accommodated the regional forces when it was convenient and raised a hue and cry against them when it was pitted against them. The local Congress leaders also encouraged the growth of regionalism and strengthened their hold on local party organization, with a view to increase their bargaining power with the central leaders. In fact a close link developed between central and regional leadership. This close link between the central and regional leadership greatly encouraged the growth of regionalism.

\section{Root Causes for Growth of Regionalism in India}

(a) Geographical factor: The territorial orientation based on geographical boundaries relate to the inhabitants of a particular region which are symbolic, at least in the Indian context. This is more so because of the linguistic distribution along geographical boundaries. The topographic and 


\section{International Journal of Science and Research (IJSR) \\ ISSN (Online): 2319-7064 \\ Index Copernicus Value (2013): 6.14 | Impact Factor (2014): 5.611}

climatic variations along with differences in the settlement pattern induce in people the concept of regionalism.

\section{(b) Historical and cultural factors:}

- In the Indian scenario, the historical and cultural factors assume greater significance. The historical and cultural components interpret regionalism by way of cultural heritage, folklore, myths, symbolism and historical traditions. People of a particular cultural group also derive inspirations from the noble deeds and glorious achievements of the local heroes. Nevertheless, there are sudden political and economic realities which can be covered under the gamut of historical and cultural factors.

- The desire of the various units of the Indian federal system to maintain their sub cultural regions and greater degree of self-government has promoted regionalism and given rise to demand for greater autonomy.

- The desire of regional elites to capture power has also led to rise of regionalism. It is well known that political parties like DMK, AIADMK, Akali Dal, Telugu Desam Asom Gana Parishad etc., have encouraged regionalism to capture power.

\section{(c) Caste and religion}

When caste is combined with language conflicts or religious fundamentalism, it breeds regional feeling. It leads to dogmatism, orthodoxy and obscurantism.

\section{(d) Economic factors}

Uneven development in many parts of the country may be construed as the prime reason of regionalism and separatism. There are certain regions in the country where industries and factories have been concentrated, educational and health facilities are adequately provided, communication network has been developed, rapid agricultural development has been made possible. But there are also certain areas where the worth of independence is yet to be realized in terms of socio-economic development. Indeed, the British administration may be held responsible for causing such wide regional variations due to their suitability for the purpose of administration, trade and commerce. But in the post-independence era, efforts should have been made for regional balance in matters of industrial, agricultural and above all, economic development. This disparity has caused the feeling of relative deprivation among the inhabitants of economically neglected regions. It has manifested itself in the demand for separate states such as Bodoland, Jharkhand, Uttarakhand, Chhatisgarh, Telangana, and so on.

\section{(e) Politico-administrative factors}

- Political parties, especially the regional political parties as well as local leaders, exploit the regional sentiments, regional deprivation and convert them to solidify their factional support bases. They give place to the regional problems in their election manifesto and promise for political and regional development.

- Regionalism made its appearance as a reaction against the efforts of the national government to impose a particular ideology, language or cultural pattern on all people and groups. Thus the States of South have resisted imposition of Hindi as official language because they feared this would lead to dominance of the North. Similarly, in
Assam anti-foreigner movement was launched by the Assamese to preserve their own culture.

- Continuous neglect of an area or region by the ruling parties and concentration of administrative and political power has given rise to demand for decentralization of authority and bifurcate of unilingual states. On occasions sons of soil theory has been put forth to promote the interests of neglected groups or areas of the state.

\section{(f) Modernization and mass participation:}

The interaction between the forces of modernization and mass participation has also largely contributed to the growth of regionalism in India. As the country is still away from realizing the goal of a nation state, the various groups have failed to identify their group interests with national interests; hence the feeling of regionalism has persisted.

\section{(g) Growing Awareness and Feelings of Regionalism:}

The growing awareness among the people of backward areas that they are being discriminated against has also promoted feeling of regionalism. The local political leaders have fully exploited this factor and tried to feed the people with the idea that the Central Government was deliberately trying to maintain regional imbalances by neglecting social and economic development of certain areas.

(h) Decline of National Sentiments: During the last a few years there has been a decline of the nationalist feeling and at the same time regional feeling are growing stronger among the people.

(i) Frustrations of Political Leaders: Sometimes the frustrations of the political leaders also gave the birth to narrow regionalism.

\section{Role of the Regional Parties}

Though the regional parties operate within very limited area and pursue only limited objective, they have played significant role both in the State as well as national politics. The regional political parties formed governments in several states and tried to give concrete shape to their policies and programmes. Some of the important regional parties which formed governments in various states include DMK and AIADMK in Tamil Nadu; National Conference in Jammu and Kashmir, Telugu Desam in Andhra Pradesh, Asom Gana Parishad in Assam; Maharasthrawadi Gomantak Party in Goa; Mizo National Front in Mizoram; Sikkim Sangram Parishad in Sikkam; All Party Hill Leaders Conference in Meghalaya and Indian National Lok Dal (INLD) in Haryana. Some of the regional parties were also partners in the coalition governments formed in several States after the fourth general elections of 1967. At the Centre also, of late the Regional Parties have been able to play critical role in helping formation of Congress government. DMK, a regional party, supported Mrs. Indira Gandhi's government after split in the party in 1969 and enabled her to carry on government despite loss of majority in the Parliament. Telugu Desam was the pillar of strengh for the United Front and later the National Democratic Alliance. The representatives of the regional parties focus the attention of the Parliament on issues in their region and try to influence 


\section{International Journal of Science and Research (IJSR) \\ ISSN (Online): 2319-7064 \\ Index Copernicus Value (2013): 6.14 | Impact Factor (2014): 5.611}

the policies of the Government to promote their own interests.

But probably the greatest service rendered by the regional political parties is that they have focused the attention of the people in remote areas on various political and economic issues and contributed to their political awakening. Above all, the regional parties have been able to impress on the national political parties that they cannot put up with their attitude of indifference towards regional problems and have compelled them to take keen interest in the resolution of their problems.

In short it can be said that the regional political parties have not only profoundly influenced the regional politics but also left tremendous impact on the national politics.

\section{Conceptual Form of Federalism}

The Sovereign Democratic Republic of India is a Union of States." The term Union instead" of a Federation" was intended to connote a higher degree of integration. Various federal constitutions were ransacked. Federation as contemplated under the Government of India Act, 1935, was also in view. After great deliberations, the foundations of the Indian Federation were laid, as envisaged under the Constitution Act of 1935 and its structure was erected after the Canadian pattern. It was deemed to be the best suited to the genius of the Indian masses.

The functioning of the American and Australian federations was also kept in view Indian Federation was the embodiment of the best part of these constitutions.

Dr. Ambedkar, the Chairman of the Drafting Committee, eulogized the term "Union of the States" on the plea that it indicated two important facts:

(a) Federalism in India had not been the result of an agreement among the units and

(b) The constituent units of the Indian Federation had no right to secede from it.

He emphasized that such an arrangement made the federation a permanent and unbreakable union.

Federalism means -Aproper respect for state functions, recognition of the fact that the entire country is made up of a Union of separate State governments, and a continuance of the belief that the National Government will fare best if the States and their institutions are left free to perform their separate functions in their separate ways". Federalism is a political concept in which a group of members are bound together by a covenant with a governing representative head. The term Federalism is also used to describe a system of the government in which sovereignty is constitutionally divided between a central governing authority and constituent political units. Federalism is a system in which the power to govern is shared between national and provincial or state governments, creating a system of governance which is called as Federation. Federalism gives the central government its authority but it also gives the states a great deal of power. On many occasions, the Supreme Court has

been called on to adjudicate what federalism means, but the Constitution puts a lot of faith in federalism what the Founding Fathers first constructed it.

It is a system of government in which a written constitution divides powers between a central government and regional or sub-divisional governments. Both types of government act directly upon the people through their officials and laws. Both types of government are supreme within their proper sphere of authority. Both have to consent to any changes to the constitution. Federalism also is referred to as a political system that binds a group of states into a larger, noncentralized superior state while allowing them to maintain their own political identities. In a federation the division of power between Federal and regional governments is usually outlined in the constitution. It is in this way that the right to self-government of the component states is usually constitutionally entrenched. Component states often also possess their own constitutions which they may amend as they see fit, although in the event of conflict the Federal constitution usually takes precedence.

\section{Characteristics of a Federation}

A federation is traditionally constituted when two or more independent neighbouring states forge a Union for defined purposes of common interest by divesting themselves of a measure of sovereignty which is vested with the federal government. The urge for union comes from the need for collective security against aggression and economic coordination for protection and expansion of trade and commerce. The federation is given only enumerated powers, the sovereignty of the states in the Union remains otherwise unimpaired".

-AFederation in USA is of this type. Alternatively, a federation is formed when a sovereign authority creates autonomous units and combines them in a Union." Once constituted, the national and state governments possess coordinate authority derived from the several constitutions and enjoy supremacy in their respective spheres of authority and jurisdiction. Canadian federation belongs to this category. However, the differences between the two lie in the degree and extent of emphasis on unitary features.

The characteristic features of a federal Constitution according to Prof. Dicey are:

1) Supremacy of Constitution;

2) The distribution among bodies with limited and coordinate authority, of different powers of government;

3) The authority of the courts as interpreters of the Constitution;

4) Double citizenship is another characteristic of some of the Federation.

No federal Constitution can completely fulfill all these characteristics. Even the Constitution of U.S.A. may not be completely federal in character. If, however, the Constitution predominantly fulfills the federal characteristics, overshadowing the unitary features, it may be categorized as Federal Constitution.

\section{Nature of Indian Federation}

\section{Volume 5 Issue 3, March 2016}




\section{International Journal of Science and Research (IJSR) \\ ISSN (Online): 2319-7064 \\ Index Copernicus Value (2013): 6.14 | Impact Factor (2014): 5.611}

The Indian Federation is a federation of its own type. It does not fall into either of the two conventional categories. The British provinces though largely autonomous after the attainment of independence in 1947 did not possess the attributes of sovereignty. Their position was just like Canadian provinces. They could not therefore form a compact of their own for common purposes of supraprovincial importance.

Moreover, the Union was not brought into existence by the British before they relinquished power. The representatives of the Indian people assembled in a Constituent Assembly and decided on the structure of the Union. Hence, they provided for the distribution of authority and functions between the national and regional governments.

On the other hand, the Indian States (Indian India) were fully autonomous according to the Independence Act, 1947. The native rulers were no longer under the suzerainty of the British. Paramountcy had lapsed. The States had the option to join India or newly carved out country-Pakistan, or remain independent. Thus their position was just like the states which constitute American federation. Hence our Federation cannot be categorized in a traditional way as a Canadian type or American type.

The independent states voluntarily form a federation. In case of India, some of the states were persuaded whereas some were coaxed and then coerced to join the Indian Union. Hyderabad may be cited as an example. The position of the provinces vis-a-vis the Centre, however, was on the Canadian pattern. Thus two different types of units were to be brought in the Union fold.

Besides, the former Chief Commissioner provinces and farflung situated once penal islands like Andaman and Nicobar were also brought in the Union. Evidently, the nature of Indian federation was to be of a peculiar type, as it was to be constituted of different types of units.

In the initial stages, the Indian Union comprised of four types of states, viz., Part A, Part B, Part C and Part D. Nine British provinces were put under Part A, nine integrated native states under part $\mathrm{B}$, the Chief Commissioner Provinces and since 1950 Vindhya Pradesh states under Part $\mathrm{C}$ and Andaman Nicobar under Part D. Thus 27 states and the territory of Andaman and Nicobar Island constituted the territory of Indian Union before the reorganization of the States on November 1, 1956. In order to achieve viability among the states and rationalize the base of the Indian Union, the States Reorganization Act, was passed which abolished old classification of states and established two types of units only i.e., States and Union Territories.

Hence, different opinions have been expressed by different critics regarding the nature of Indian Federation. According to Dr. Where, the Indian Constitution establishes a -system of government which is at most quasi-federal, almost revolutionary in character; a unitary state with subsidiary federal features rather than federal state with unitary features." Dr. Krishna P. Mukerjee remarks Ihave come to take the view that whatever might have been the position at the drafting stage or previous to that stage the Constitution that emerged out of the august deliberations of the Constituent Assembly of India in January, 1950 is definitely un-federal or unitary Constitution."

Dr. Ambedkar, is of the view. The Constitution has been set in a tight mould of federalism." Sir Ivor Jennings opines India has a federation with a strong centralizing tendency." Dr. Gajendragadkar, former Chief Justice of India, observed, though it partakes of some of the characteristics of federal structure it cannot be said to be federal in the true sense of the term." Dr. K.M. Munshi, a distinguished jurist, portrayed Indian Federation as a quasi-federal union invested with several important features of a unitary government."

In fact the Indian Constitution can be unitary or federal according to requirements of time and circumstances. Rightly remarks D.D. Basu The constitution of India is neither purely federal nor unitary, but is a combination of both. It is a union or a composite of novel type." Pandit Nehru who had used the word federation" a number of times in the Assembly once described the states as -rare administrative units" in one of his off-hand speeches.

Dr. Deshmukh summed up the nature of Indian federation as —aither federal nor unitary." According to Sardar Patel -. Our new Constitution is not an alliance between democracies and dynasties but a real union of the Indian people based on the basic concept of the sovereignty of the people."

The Indian Constitution, no doubt, fulfills some conditions of a federation, but it leans towards a strong Centre, it is a stable union of states and provinces (now termed as states) which have neither lost their entities nor claim complete autonomy. Evidently it does not violate the essentials of a federal polity. However, our federal system has been adjusted to the needs of our country, which has been falling prey to the foreign invaders on account of it being a house divided against it.

Hence it has been correctly portrayed -our Constitution is neither truly federal nor unitary in character but is really a cross-section or a mixture of the two structures though it leans more in favour of the federal rather than the unitary structure."

An analytical appraisal of the working of our Constitution during over five decades reveals that the unitary bonds have been further strengthened but not at the cost of its federal character. Considering the dominance of regional parties in the United Front (U.F.) which formed the Government after the 11th Lok Sabha polls and emergence of hung Parliament, the first UF Prime Minister Deve Gowda resolved to advance the principles of political, administrative and economic federation. There emerged a broad consensus among the political parties on the need for healthy federation.

An Editorial commented, $-\mathbb{N}$ attempt should be made to make the states stronger at the cost of the Centre. Any idea of weakening the Centre should be nipped in the bud and it goes to the credit of the United Front that in its concept of 


\section{International Journal of Science and Research (IJSR) \\ ISSN (Online): 2319-7064 \\ Index Copernicus Value (2013): 6.14 | Impact Factor (2014): 5.611}

federation a strong Centre and the strong states are complementary." In fact the Centre and the units draw strength from each other. Keeping in view the functioning of Central Government after Xllth and XIIIth Lok Sabha polls, emergence of hung parliaments and coalition governments and pivotal role of regional parties in running this government, the necessity of cooperative federalism has become imperative.

The formation of UPA after XIVth and XVth Lok Sabha elections held in April-May, 2004 and May, 2009 portray other examples of coalition's governments which are functioning smoothly despite occasional irritants on vital issues by the coalitional allies.

\section{Role of Political Parties in Balancing Federalism and Regionalism}

Years around independence, India can be taken as a society of statelessness. In the pre-independence days Congress provided the platform for the rallying cry of 'Swaraj' and made itself the recognized spokesman of the feeling of vague revolt and common identity. Its working for the independence provided a focus around which both elite and mass could unite. Here, elites were united by ties of friendship, frequently reinforced by common educational and agitational experiences and by dedication to the nationalist issue. Because of the lack of modern structures, there was no serious competition. Congress was well organized and led a responsive movement capable of disciplined action in response to directives from the top. Congress was able to ferret out and exploit feelings of dissatisfaction among the masses against the British for political ends. The mass movement became the frame work within which primordial differences among the population could be submerged in the search of common goal.

After independence it was felt by the top leaders of the Congress that there should be a new setup for the states and the people should have loyalty towards a stable governing regime and should not have divisive tendencies. Congress did this exercise skillfully. It silenced the little tradition of primordial loyalties by focusing attention upon the problems of and military alliances. At the same time Congress set for itself, the twin goal of national integration and socioeconomic development. It felt that political identity in a nation State begs the idea that loyalty and commitment of the individual should be extended only to the territorially defined nation State.

Our government was extremely determinate in building the complex state instruments of adult franchise, parliamentary institutions, neutral bureaucracy, Rule of Law, quasiFederalism, local institutions, planning capitalist path of development, public enterprises, secularism and socialistic pattern of society. Moreover, the government was always willing to trait, behind the events so as to equip itself to make authoritarian decisions, while subduing primordial forces. At the same time we set for ourselves, the twin goal of national integration and socio-economic development. In short we can say that the system was potent and practical enough to equip itself politico- economically and sociopolitically to deal with the phenomenon of regionalism. But regional imbalances, economic and political in equality, Centre's indifference to a particular region are the various factors which have led to strong feeling of regionalism in India.

Regionalism in India is a countrywide phenomenon, often tends to take the form of well conceived and well organized agitations and campaigns. Political/ Regional movements take four forms:

- Demand of the people of certain area for separate statehood.

- Demand of the people of certain area for secession from the Indian Union.

- Demand of the people of certain union territories for full Fledged statehood, and

- The demand of certain people for favourable settlement in inter-state disputes.

Dravida Munetra Kazhagam and Dravida Kashagam of Tamil Nadu and Alkali Dal of Punjab, the Mizos of Assam, the Nages of Assam all had demanded secession from the Indian union at one period or another. The demand for the state of Andhra Pradesh triggered the like demands in the country. The demands for Gujrat, Punjab, Telengana, Vidhrah and others voiced the regional problem. In a similar fashion the union territories also demanded full-fledged state-hood. Himachal Pradesh and Tripura obtained statehood in this manner. Regionalism was intense on the question of boundary dispute of Maharashtra and Mysore, Punjab, Haryana and Tamil Nadu and Andhra Pradesh. Regionalists and nationalists find themselves in acute conflict in six major areas. They are:

- Language policy

- Educational policy

- Resource allocation

- Mass media control

- Electoral competition

- Using the state machinery under its complete control.

On the question of the role of the regional parties, an assessment of present characteristic of those parties must, first be made. In the Indian context regional parties are those, which generally and exclusively operate within limited geographical area of a state, or which represented primordial loyalties. The regional parties stand in sharp contrast to the broad ranging diverse concerns of national parties in a country of vast diversity like India, where political fluidity continues indefinitely because of the transitions from the traditional caste politics to democratic mass politics. Primordial groups were the First ones to demand regional identity and personalities of their own. For instance, the Jharkhand party aims at establishing a Jharkhand state for a few millions primitive tribals, who live in the plateau of Chota Nagpur of Bihar, and some district of Orissa and Madhya Pradesh and Bengal. The Akalidal, the political mouth piece of the Sikhs, is a regional party with a religious base, The Dravida Munetra Kazahagan stands for the welfare of the backward communities of Tamilnadu, Shivsena of Bombay under the leadership of Bal Thakery has assumed a militant posture against the nonMaharashtrian, Telgu Desam of Andhra and National conference of Jammu and Kashmir has fomented caste, 


\section{International Journal of Science and Research (IJSR) \\ ISSN (Online): 2319-7064 \\ Index Copernicus Value (2013): 6.14 | Impact Factor (2014): 5.611}

communal, linguistic and regional feelings. The GNLF has demanded autonomy for Darjeeling district of West Bengal. Thus every conceivable category of primordial sentiments in India has found a regional party of its own.

On the other hand, thrusting of a modern political consciousness upon the mass of a still largely not modernized population has tended to lead to the stimulation of intense popular interest. The institutionalization of political participation has not progressed sufficiently to accommodate the rising demands of the masses by the political parties. Thus, the absence of a balance between the rate of growth of political participation and the rate of institutionalization of the people within the national political parties, had led to the emergence of several regional parties. Congress itself has been subject, to this test. Kerala Congress, Tamil Arasu Kazhagam, Bhartiya Krantidal, Jana Congress, Indian National Democratic Congress were the instances of this phenomenon. It has been not only the Congress, that gave rise to despair but several regional parties themselves were responsible for this happening.18 There has been continuous breeding of regional parties by regional parties themselves. All India Anna Dravida Munetra Kazahagam, Republican Party of India (Kamble group), Jharkhand Party, Jharkhand Mukti Morcha, Jharkhand Peoples Party various factions in the Akalidal can be cited as example of this.

In a plural society and a federal polity like ours, some kind of regional commitment is but natural. When regionalism becomes a threat to national unity, and breeds communal disharmony, it deserves no sympathy. Regionalism as a factor of balkanization is a continuous threat for the people of India. The politics of fragmentation may not be that successful, but the country has to face its dangerous consequences like factionalism, class conflict and group rivalries.

The government of India needs to adopt a constructive approach to balance federalism and regionalism. Now in the coming days of internationalism, the people and the political parties of India need to join hands, so that they can play an important role in promoting unity and integrity of India.

\section{Role of Regionalism on politics}

- The Feeling of Regionalism: The feeling of regionalism has produced the feeling of separatism among the people living in different parts of India.

- Violent Movement: Regionalism has given birth to violent movements.

- Demand of States for More Autonomy: Although several factors are responsible for the demand of more autonomy for the states, but one of the reasons is that with the granting of more autonomy to the states they will be able to develop their regions.

- Demand for Separate States: The People living in the backward regions of India are demanding separate states.

- Tension between Centre and States: The people living in different states allege that centre is not taking any special interest in the development of their state, and thus the discriminination is being made with them.
- Formation of Regional Parties: Due to high feeling of regionalism, several regional political parties have come into existence and they give priority to regional interests over the national interests.

- Politics of Movements: The impact of politics of movements is increasing in India day by day. People living in different parts of India launch movements from time to time to attract the attention of the central government. For example:

- Theory of the Sons of the Soil: For example: Maharastra for Maharastra, Bengalies for Bengalies etc.

\section{Suggestive Measures for Correcting Regional Imbalances}

Regionalism has been an important aspect of Indian politics. Sometimes, it has posed threat to the unity of the country. Hence it is necessary to take steps to reduce such tendencies. Some such measures can be

- Doing away with regional imbalance

- Check on regional political parties

- Top priority to the economic development of deprived zones

- Restructuring of the society

- Acculturation

- Developed means of transport and communication

- Proper and Right type of education

- Appeal through mass media

- Proper organization of Regional Parties

- Efforts for the balance progress of different states

- Activities of the separatists should be dealt with strongly

- Establishment of Autonomous Commissions to settle Inter-state Disputes

- Balanced Division of Powers between Centre and the States

- Development of Secular Politics

- Redress of the grievance of the Minorities

- Need to review the Federal Structure

- More administrative and Financial Autonomy to States

\section{Conclusion}

Regionalism means strong attachment to a particular region or a state as against the country as a whole. This feeling arises either due to the continuous neglect of a particular area or because the people of a particular region become politically aware and seek to fight perceived discrimination. Regionalism is a problem because it threatens the unity and integrity of the country. The two prominent manifestations of regionalism are: (a) Agitation for separate statehood. Examples, demand for Telengana, Bodo-land (Assam), Gorkha land etc., and (b) Secession from the Indian Union, for example - demand for Khalistan, demand for Nagaland, etc. So, there should be needed to promote even development of the hitherto neglected areas so that they feel a part of the national mainstream. The central government must not interfere in the affairs of the State unless it is unavoidable for national interest. Problems of people must be solved in a peaceful and constitutional manner. Politicians must not be allowed to misuse the issue of regional demands. Except for issues of national importance, 


\section{International Journal of Science and Research (IJSR) \\ ISSN (Online): 2319-7064 \\ Index Copernicus Value (2013): 6.14 | Impact Factor (2014): 5.611}

the states should be given freedom to run their own affairs. Changes are necessary in the Central-State relations in favour of the states, and for introducing a system of national education that would help people to overcome regional feelings and develop an attachment towards the nation. If, these are possible to plan, implement and effectuate, then we can be fulfilled by the unique proud of the greatest democracy with the greatest harmony having lot of varieties in natural and anthropogenic landscapes. Finally, the problem of regionalism can not be solved fully, yet its effect can be minimized. For the achievement of this objective, proper understanding should be among the people and attention should be given to the balanced development of the people.

\section{References}

[1] Adhikari, S (2003), Raison d' etre-State-Idea of Bangladesh: A Politico-Geographical Appraisal', Geographical Review of India, Vol. 66, No. 3, pp. 229241.

[2] Adhikari, S (2008), Political Geography of India: A Contemporary Perspective, Allahabad, Sharda Puatak Sadan.

[3] Aiyar, S.P. \& Mehta, Usha (eds): Essays on Indian Federalism (Bombay: Allied, 1965).

[4] Banerjee, A. K (2002), Geopolitical Environment and Security: India and her Neighbours', in S. R. Basu (ed) Changing Environment Scenario of the Sub-continent, Kolkata, ACB Publications.

[5] Bhatnagar, S. and Pardeep Kumar (eds.), Regional Political Parties in India, Ess Publications, New Delhi, 1988.

[6] Chakrabarthy, Bidyut, Forging Power: Coalition Politics in India, Oxford Press, New Delhi. 2006.

[7] Chandra, Praksh, Coalition Politics in India, Anmol Publications, New Delhi, 2006.

[8] Das, Hari Hara \& Mohapatara, S: Centre-State Relations in India (New Delhi: Ashish Publishing House, 1986).

[9] Dutta B. (1996): Coalition Governments and Fiscal Policies in India, ISI Delhi, mimeo.

[10] Johri, S.R.: Dark Corner of India (Lucknow: Himalaya Publishers, 1970).

[11] Kumar, D.P.: Challenge to India's Unity (Delhi: B.R.Publications, 1990).

[12] Kumar, Pradeep: "Communal Dimension of Regionalism in the Indian Federation" in Majeed, Akhtar (ed), op.cit. , pp.145-158.

[13] Khan, R.: "Problems of Nation Building" World Focus, Vol.4, No.11-12, Nov-Dec 1983, pp.11-15.

[14] Mukherji, Partha N.: "Class \& Ethnic Movements in India: In Search of a Pertinent Paradigm for Democracy \& Nation-Building" in Lars, Rudebeck (ed) : When Democracy Makes Sense (Sweden: Uppsala University, 1992) pp.13-30.

[15] Nehru, Jawaharlal (1946): The Discovery of India, The John Day Company, New York.

[16] Pal, Chandra: State Autonomy in Indian Federalism: Emerging Trends (New Delhi: Deep \& Deep Publications, 1984) .

[17] Palshikar, Suhas (2003): " The Regional Parties and Democracy", Ch. 13, pp. 306-35 in Ajay K. Mehra,
D.D. Khanna and Gert W. Kueck (Eds): Political Parties and Party Systems. Sage Publications, New Delhi.

[18] Parathasarathy, G (2010), We Can Work Out, The Times of India.

[19] Prakash, Amit (2003), "Social, Cultural and Economic Dimensions of the Party System" in Ajay K. Mehra, D.D. Khanna and Gert W. Kueck (eds). Political Parties and Party Systems. New Delhi: Sage, pp. 129- 161.

[20] Reddy, G.Ram \& Sharma, B.A.V.(eds): Regionalism in India: A Study of Telangana (New Delhi: Concept Publishing House, 1979).

[21] Singh, Mehindra Prasad and Anil Mishra, Coalition Politics on India: Problems and Prospects, Manohar Publishers, New Delhi, 2004.

[22] Srinivasan, T.N. and Suresh D. Tendulkar (2003): Reintegrating India With the World Economy, Institute for International Economics, Washington, D.C. and Oxford University Press, New Delhi.

[23] Subba, Tanka B. : Ethnicity, State \& Development: A Case Study of the Gorkhaland Movement in Darjeeling (New Delhi: Har-Anand \& Vikas Publishers, 1992).

[24] Sukhwal, B.L.: India: A Political Geography (New Delhi: Allied Publishers, 1971) .

[25] Sundaram, K. and Suresh D. Tendulkar (2003): "Poverty among Social and Economic Groups in India in 1990s", Economic and Political Weekly, Vol. 38, No. 50, December 13, pp. 5263-76

[26] Thakurta, Paranoy Guha and Reguraman Shankar, A Time of coalitions: Divided we stand, Sage Publications, New Delhi, 2004.

[27] Thorner, Daniel (1980): Shaping of Modern India, Allied Publishers, New Delhi.

[28] Urmila, Phadnis: Ethnicity \& Nation-Building in South Asia (New Delhi: Sage Publishers, 1990).

[29] Varshney, Ashutosh (1995), Democracy, Development and the Countryside: Urban-Rural Struggles in India, Cambridge University Press, Cambridge, U.K. 